\title{
Metabolization of Insecticidal Amides from Leaves of Piper tuberculatum by Heraclydes hectorides and Naupactus bipes
}

\author{
Clécio S. Ramos, ${ }^{\circledR a}$ Marcílio W. F. Silva, ${ }^{a}$ Marcilio M. Moraes, ${ }^{b}$ Argus V. Almeida, ${ }^{c}$ \\ Sérgio A. Vanin ${ }^{d}$ and Massuo J. Kato ${ }^{\odot *, b}$ \\ ${ }^{a}$ Departamento de Química, Universidade Federal Rural de Pernambuco, \\ Dom Manoel de Medeiros, 52171-030 Recife-PE, Brazil \\ ${ }^{b}$ Departamento de Química Fundamental, Instituto de Química, Universidade de São Paulo, \\ 05508-000 São Paulo-SP, Brazil \\ 'Departamento de Biologia, Universidade Federal Rural de Pernambuco, \\ Dom Manoel de Medeiros, s/n, 52171-030 Recife-PE, Brazil \\ ${ }^{d}$ Instituto de Biociências, Universidade de São Paulo, 05513-970 São Paulo-SP, Brazil
}

\begin{abstract}
Amides have been recognized as potent insecticidal natural products but, despite their variety of targets and mechanisms of action, their metabolic fate in insects is virtually unknown. The currently accepted hypothesis is that specialist herbivores are capable of biotransforming xenobiotics rendering them more polar and excretable while generalist insects do not have comparable capacity. The leaves from Piper tuberculatum, rich in insecticide amides, were offered to two insect species found on Piper leaves under natural conditions and also to four generalist grasshoppers in order to compare their capacity of biotransforming xenobiotics. The amides 1-7 were identified in the P. tuberculatum leaves and their corresponding carboxylic acids 8-13 were detected in frass samples of two host insects suggesting that these species promote the amides hydrolysis. The four generalist grasshoppers when offered $P$. tuberculatum leaves, starved to death after $72 \mathrm{~h}$, indicating a strong antifeedant activity of $P$. tuberculatum leaves.
\end{abstract}

Keywords: Piper tuberculatum, Piperaceae, amides, metabolization, insects

\section{Introduction}

Natural amides found in members of the Piperaceae family have received considerable attention due to their potent insecticidal activity against several agricultural pests. ${ }^{1-9}$ The isobutyl amides pellitorine and 4,5-dihydropiperlonguminine isolated from Piper tuberculatum seeds have shown 100\% mortality at doses of 200 and $700 \mu \mathrm{g}$, respectively, to the velvetbean caterpillar Anticarsia gemmatalis (Lepidoptera: Noctuidae), a typical pest of beans, peanuts, soybeans, cotton, kudzu, alfalfa, cowpeas, horse beans, snap beans, lima beans, and coffee weeds. ${ }^{1}$ The 4-methylpentyl amides pipnoohine and pipyahyine isolated from $P$. nigrum fruits exhibited toxicity at 35 and $30 \mathrm{ppm}$, respectively, against fourth-instar larvae of Aedes aegypti. ${ }^{10}$

The most abundant amides from $P$. nigrum fruits piperine and piperiline and some of their analogues had

*e-mail: majokato@iq.usp.br their topical toxicity evaluated against several natural pests including Ascia monuste orseis (Lepidoptera: Pieridae), Acanthoscelides obtectus (Say) (Coleoptera: Bruchidae), Brevicoryne brassicae (L.) (Hemiptera: Aphididae), Protopolybia exigua (Hymenoptera, Vespidae) and Cornitermes cumulans (Isoptera, Nasutitermitinae). ${ }^{11}$ The $N, N$-diisopropyl analogue of piperine was the most active against $A$. monuste orseis. Guineensine, an isobutyl amide isolated from seeds of $P$. guineense, showed insecticidal activity $(0.84 \mu \mathrm{g}$ per male; $48 \mathrm{~h}$, lethal dose $\left.50 \%\left(\mathrm{LD}_{50}\right)\right)$ when tested topically on the cowpea weevil Callosobruchus maculatus. Amides such as piperettine, piperine, thichonine and piplartine were toxic to fruit flies and to several other insect species. ${ }^{12}$ Pipericide from $P$. nigrum showed insecticidal activity against the adzuki bean weevil Callosobruchus chinensis. ${ }^{13}$ Piper cenocladum is protected against herbivores by a mutualistic interaction with ants and also contains the amides piplartine, 4'-demethylpiplartine and cenocladamide. ${ }^{14}$ P. cenocladum 
tissues from which ants were removed had significantly higher concentrations of total amides, indicating that amides are part of the plant defense system. ${ }^{15}$ Recent studies $^{16-18}$ have revealed that new synthetic amides have promising insecticidal activity. Novel chiral amides as (2Z)-N,N-diethyl-3-[(4S)-2,2-dimethyl-1,3-dioxolan4-yl]prop-2-enamide and (2Z)-N,N-diisopropyl3-[(4S)-2,2-dimethyl-1,3-dioxolan-4-yl]prop-2-enamide were effective against the beetle Rhyzopertha dominica (Coleoptera: Bostrichidae), one of the main wheat pest, with mortality comparable to the commercial insecticide Bifenthrin ${ }^{\circledR} .{ }^{16}$ The trifluoromethylphenyl amides showed potential mosquitocides and repellents properties against Aedes aegypti mosquitoes, ${ }^{17}$ while phenolic acid amides showed moderate to good insecticidal activity with the lowest $\mathrm{LC}_{50}$ value of $63 \mathrm{ppm}$ against brown planthopper (Nilaparvata lugens). ${ }^{18}$

In summary, amides are generally associated to the chemical defense strategy in plants because of their potent insecticidal or repellent action against a broad range of insect species but, despite the variety of activities, their metabolic fate in insects is virtually unknown. Thus, as part of the study of metabolism of plant secondary compounds by insects, ${ }^{19-24}$ herein we describe the metabolism of the major amides from leaves of $P$. tuberculatum by the insects Heraclides hectorides (Lepidoptera: Papilionidae) and Naupactus bipes (Coleoptera: Curculionidae), which are observed as herbivores of $P$. tuberculatum leaves in the field. For comparison purposes, four generalist herbivores Elaeochora trilineata (Orthoptera: Romaleidae), Chromacris speciosa (Orthoptera: Romaleidae), Tropidacris collaris (Orthoptera: Romaleidae) and Xyleus discoideus (Orthoptera: Romaleidae) were also offered leaves of $P$. tuberculatum to test the hypothesis that specialization on Piper hosts correlates with biotransformation of their toxic amides as a mechanism to circumvent toxicity.

\section{Experimental}

Plants

Piper tuberculatum Jacq. var. tuberculatum leaves Jacq. were collected from specimens growing in the garden of the Institute of Chemistry (University of São Paulo) in São Paulo state, Brazil. The specimen was identified by Dr Elsie F. Guimarães (Instituto de Pesquisas Jardim Botânico do Rio de Janeiro). A voucher specimen (Kato-0240) was deposited at Herbarium of the Instituto de Botânica (Secretaria de Estado do Meio Ambiente).
Insects

Naupactus bipes (Germ., 1824) (Curculionidae, Coleoptera) and Heraclides hectorides (Esper, 1794) (Papilionidae, Lepidoptera) were collected in the Campus of the University of São Paulo (USP) and were identified by Dr Sérgio A. Vanin (Instituto de Biociências e Museu de Zoologia-USP). Voucher specimens of $N$. bipes (CSR-001) and H. hectorides (CSR-006) were deposited at the Museu de Zoologia da Universidade de São Paulo. The specimens of $N$. bipes adults and $H$. hectorides were reared in the laboratory and maintained in cages under artificial light $(15 \mathrm{~h}$ light- $9 \mathrm{~h}$ dark) at room temperature $\left(24 \pm 2{ }^{\circ} \mathrm{C}\right)$ and relative humidity of $72 \pm 10 \%$ for a month with diet consisting of leaves of $P$. tuberculatum. The grasshoppers (Orthoptera: Romaleidae) Elaeochora trilineata (Serville, 1831), Chromacris speciosa (Thunberg, 1824), Tropidacris collaris (Stoll, 1813) and Xyleus discoideus angulatus (Stal, 1873) were collected at Dois Irmãos State Park (Recife, PE, Brazil) and identified by Dr Argus Vasconcelos de Almeida (Department of Biology, UFPRE). The grasshopper species were reared separately in cages in the University's entomology laboratory, and fed on leaves of Mangifera indica (T. collaris), Solanum paniculatum leaves (C. speciosa and X. discoideus) and Ipomoea alba (E. trilineata) for several generations under artificial light (15 h light-9 h darkness) at a temperature of $30 \pm 2{ }^{\circ} \mathrm{C}$ and relative humidity of $72 \pm 10 \%$. Voucher specimens of E. trilineata, C. speciosa, T. collaris and X. discoideus were deposited in the same laboratory. The insects were then left starving for $24 \mathrm{~h}$ and offered exclusively $P$. tuberculatum leaves. Only $X$. discoideus was capable to feed the leaves and the initial frass collected in the subsequent $2 \mathrm{~h}$ were discarded and then collected for $48 \mathrm{~h}$. The frass from $X$. discoideus were freeze-dried and maintained under $-20{ }^{\circ} \mathrm{C}$ until chemical analyses were carried out.

\section{Instruments}

Gas chromatography mass spectrometry (GC-MS) analyses were carried out using a Shimadzu system (CG-MS-QP2010, Ultra) operating in the electron ionization (EI) mode at $70 \mathrm{eV}$ with a $\mathrm{Rxi}^{\circledR}-5 \mathrm{~ms}$ (Crossbond 5\% diphenyl/95\% dimethyl polysiloxane; $30 \mathrm{~m} \times 0.25 \mathrm{~mm} \times 0.25 \mu \mathrm{m})$ column. The oven temperature increased from 100 to $280{ }^{\circ} \mathrm{C}$ at $6{ }^{\circ} \mathrm{C} \mathrm{min}{ }^{-1}$ and a carrier gas (helium) was used at flow rate of $1 \mathrm{~mL} \mathrm{~min}{ }^{-1}$. Injector and detector temperatures were $260{ }^{\circ} \mathrm{C}$. ${ }^{1} \mathrm{H}$ nuclear magnetic resonance (NMR) was recorded at $300 \mathrm{MHz}$ (Bruker 300, Bruker BioSpin GmbH, Rheinstetten Germany). Samples were dissolved in $\mathrm{CDCl}_{3}$, with tetramethylsilane (TMS) as 
internal standard. Thin layer chromatography (TLC) was performed on pre-coated silica gel $60 \mathrm{~F}_{254}$ plates. Spots were visualized under UV light ( 254 and $365 \mathrm{~nm}$ ) and by spraying with ceric sulfate followed by heating.

Extraction, isolation and analysis of amides 1-7

The extraction and isolation of the amides 1-7 from P. tuberculatum were carried out as previously reported..$^{25,26}$

Isolation of the compounds 8-13

Freeze dried frass of $N$. bipes $(150 \mathrm{mg})$ and H. hectorides (400 mg) fed on leaves of $P$. tuberculatum were milled and extracted with EtOAc $(10 \mathrm{~mL})$ three times. The concentration of the EtOAc solutions under vacuum yielded 55 and $118 \mathrm{mg}$ of crude extracts, respectively. These extracts were dissolved in EtOAc $(50 \mathrm{~mL})$ and extracted with a solution of $\mathrm{NaOH}\left(1 \mathrm{~mol} \mathrm{~L}^{-1}, 20 \mathrm{~mL}\right)$ three times. The aqueous solution was acidified with $\mathrm{HCl}$ (conc.) to $\mathrm{pH} 5.0$ and extracted three times with EtOAc. The organic phase was extracted with water until neutralization and dried over anhydrous $\mathrm{Na}_{2} \mathrm{SO}_{4}$, then concentrated under vacuum yielding 15 and $49 \mathrm{mg}$ of acidic fraction, respectively. These fractions were further purified over a silica $\mathrm{C}_{18}$ cartridge (Waters, $500 \mathrm{mg}$ ) using $\mathrm{H}_{2} \mathrm{O}: \mathrm{MeOH}(2: 3)$ as eluent and further submitted to silica gel prep-TLC eluted with hexanes-EtOAc (3:2) yielding $8(2.0 \mathrm{mg})$, $\mathbf{9}(1.5 \mathrm{mg}), \mathbf{1 0}(2 \mathrm{mg}), \mathbf{1 2}(1 \mathrm{mg})$ and $\mathbf{1 3}(4 \mathrm{mg})$ from frass of $H$. hectorides and $\mathbf{1 1}(8 \mathrm{mg})$ from frass of $N$. bipes.

\section{Preparation of piperic acid}

Piperine $(0.35 \mathrm{mmol})$ was refluxed with ethanolic $\mathrm{KOH}$ $\left(2 \mathrm{~mol} \mathrm{~L}^{-1}\right)$ for $2 \mathrm{~h}$. Ethanol was evaporated under reduced pressure and cooled in ice salt bath. The solid potassium salt of piperic acid was suspended in hot water and acidified with hydrochloric acid, yellow precipitate was collected, washed with cold water and recrystallized from ethanol yielding $68.8 \mathrm{mg}$ of piperic acid (90\% yield). ${ }^{27}$

Saponification of the crude extract from leaves of P. tuberculatum

An amount of $30 \mathrm{mg}$ of leaf extract (EtOAc) was dissolved in dimethyl sulfoxide (DMSO) $(10 \mathrm{~mL})$ and treated with a solution of $\mathrm{KOH} 2 \mathrm{~mol} \mathrm{~L}^{-1}(5 \mathrm{~mL})$ and heated at $40{ }^{\circ} \mathrm{C}$ for $10 \mathrm{~h}$. The solution was then acidified with $\mathrm{HCl}$ (conc.) to $\mathrm{pH} 5$ and extracted with EtOAc $(15 \mathrm{~mL}$, three times). The organic phase was extracted twice with brine, dried over anhydrous $\mathrm{Na}_{2} \mathrm{SO}_{4}$ and concentrated under vacuum yielding $3 \mathrm{mg}$ of a fraction, which was analyzed by GC-MS. ${ }^{27}$

\section{3,4,5-Trimethoxycinnamic acid (8)}

$\mathrm{C}_{12} \mathrm{H}_{14} \mathrm{O}_{5}$; EI-MS, $\mathrm{m} / \mathrm{z}$ (rel. int.): $238[\mathrm{M}]^{+\bullet}(100)$, 223 (48), 163 (23) and 181 (13). Identified by comparison with authentic standard and with that reported. ${ }^{28}$

\section{3,4,5-Trimethoxyphenyl-propanoic acid (9)}

${ }^{1} \mathrm{H}$ NMR (300 MHz, $\left.\mathrm{CDCl}_{3}\right) \delta 6.44$ (s, 2H, H-2 and $\mathrm{H}-6), 3.84\left(\mathrm{~s}, 6 \mathrm{H}, 3-\mathrm{OCH}_{3}\right.$ and $\left.5-\mathrm{OCH}_{3}\right), 3.82(\mathrm{~s}, 3 \mathrm{H}$, 4- $\mathrm{OCH}_{3}$ ), 2.91 (t, J $\left.5.6 \mathrm{~Hz}, 2 \mathrm{H}, \mathrm{H}-8\right), 2.68(\mathrm{t}, J 5.6 \mathrm{~Hz}, 2 \mathrm{H}$, H-7); EI-MS, $m / z$ (rel. int.): $240\left[\right.$ [M] ${ }^{+*}(100), 225$ (60), 195 (13) and 181 (90), compared with authentic standard and similar to that reported. ${ }^{29}$

\section{3,4,5-Trimethoxybenzoic acid (10)}

${ }^{1} \mathrm{H}$ NMR $\left(300 \mathrm{MHz}, \mathrm{CDCl}_{3}\right) \delta 7.39(\mathrm{~s}, 2 \mathrm{H}, \mathrm{H}-2$ and $\mathrm{H}-6), 3.94$ (s, 3H, 4- $\left.-\mathrm{OCH}_{3}\right), 3.93$ (s, 6H, 3- $\mathrm{OCH}_{3}$ and 5-OCH ${ }_{3}$ ); EI-MS, $m / z$ (rel. int.): 212 [M] ${ }^{+\bullet}(100), 197$ (66), 169 (20) and 141 (41), compared with authentic standard and similar to that reported. ${ }^{29}$

Piperic acid (11)

${ }^{1} \mathrm{H}$ NMR $\left(300 \mathrm{MHz}, \mathrm{DMSO}-d_{6}\right) \delta$ 7.33-7.26 (m, $\left.1 \mathrm{H}\right)$, $7.25(\mathrm{~s}, 1 \mathrm{H}), 7.03-6.92(\mathrm{~m}, 4 \mathrm{H}), 6.06(\mathrm{~s}, 2 \mathrm{H}), 5.90(\mathrm{~d}$, $J 15.2 \mathrm{~Hz}, 1 \mathrm{H}$ ); EI-MS, $m / z$ (rel. int.): 218 [M]+• (37), 173 (64), 143 (31) and 115 (100), compared with authentic standard and similar to that reported. ${ }^{30}$

\section{7,8-Dihydropiperic acid (12)}

EI-MS, $m / z$ (rel. int.): $220[\mathrm{M}]^{+*}(1.2), 174$ (12), 135 (100) and 77 (15), compared with authentic standards and similar to that reported. ${ }^{31}$

Piperonylic acid (13)

${ }^{1} \mathrm{H}$ NMR (200 MHz, DMSO- $\left.d_{6}\right) \delta 7.75$ (dd, $J$ 8.5, $2.5 \mathrm{~Hz}, 1 \mathrm{H}, \mathrm{H}-6), 7.52$ (d, J $2.5 \mathrm{~Hz}, 1 \mathrm{H}, \mathrm{H}-2), 6.89$ (d, $J 8.5 \mathrm{~Hz}, 1 \mathrm{H}, \mathrm{H}-5$ ), 6.07 (s, 2H); EI-MS, $m / z$ (rel. int.): $166[\mathrm{M}]^{+*}(97), 165$ (100), 149 (38), 119 (26) and 63 (46), compared with authentic standard purchased from Sigma Aldrich (St. Louis, USA).

\section{Results and Discussion}

The insects $N$. bipes (adults), H. hectorides (caterpillars), E. trilineata (adults and nymphs), C. speciosa (adults and nymphs), $T$. collaris (adults and nymphs) and $X$. discoideus (adults and nymphs) were offered exclusively fresh P. tuberculatum leaves for $72 \mathrm{~h}$. While the weevil $N$. bipes (adults), the caterpillar H. hectorides and grasshoppers 
$X$. discoideus consumed the leaves, the grasshoppers (adults and nymphs) of C. speciosa, E. trilineata and T. collaris, did not feed, possibly because of the leaves deterrence, starving to death. The insects $X$. discoideus, H. hectorides and $N$. bipes on contact with leaves of $P$. tuberculatum responded by reducing food intake as compared with leaves of P. solmsianum..$^{23}$ The analysis of the crude extract from P. tuberculatum leaves by GC-MS indicated the presence of amides 1-7 (Figure 1).

The possibility of biotransformation of amides (1-7) found in leaves of $P$. tuberculatum during the digestive process of $X$. discoideus, $H$. hectorides and $N$. bipes was investigated under laboratory conditions. Frass samples of the three species fed on leaves of $P$. tuberculatum were collected and freeze-dried. The dried frass were extracted with EtOAc and analyzed by GC-MS. The chemical profile of $X$. discoideus frass was similar to that from P. tuberculatum leaf extracts (data not shown), suggesting that the amides 1-7 did not undergo detectable biotransformation during the grasshopper's digestive process leading to the formation of compounds of similar polarity. On the other hand, the chromatograms of the frass extracts of $H$. hectorides and $N$. bipes displayed six additional peaks (8-13) not detectable in the chromatograms of the leaf extracts (Figure 2). Thus, the frass extracts were submitted to purification steps, yielding the isolated compounds 8-13.

The structures of the compounds $\mathbf{8 - 1 3}$ were determined based on the analysis of MS and ${ }^{1} \mathrm{H}$ NMR data and identified as 3,4,5-trimethoxycinnamic acid (8), 3-(3',4',5'-trimethoxyphenyl)-propanoic acid (9), 3,4,5-trimethoxybenzoic acid (10), piperic acid (11), 7,8-dihydropiperic acid (12) and piperonylic acid (13), as previously reported from other Piper species. ${ }^{28,29}$

The analysis of the set of GC-MS chromatograms allowed to draw a hypothesis on the biotransformation of the amides by the herbivores. The amide piplartine (1) was partially hydrolyzed into the corresponding carboxylic acid $\mathbf{8}$ during the digestive process of $P$. tuberculatum leaves by $N$. bipes and $H$. hectorides. The amide 2 was fully hydrolyzed by both insects, producing the carboxylic acid $\mathbf{9}$. The benzoic acid $\mathbf{1 0}$ could be either a product from the oxidative cleavage of $\mathbf{1}$ as well as from the cinnamic acid $\mathbf{8}$. Metabolite $\mathbf{1 1}$ could originate from the partial hydrolysis of amides 3 and/or $\mathbf{6}$. The 7,8-dihydropiperic acid (12) could be produced similarly from the amides $\mathbf{4}$, 5 and/or 7, while the piperonylic acid (13) could be a product of oxidative cleavage of amides 3-6 and/or from the carboxylic acids 11-12 (Figure 3).

The amides from Piper species have been described as insecticidal or deterrent against generalist herbivores, ${ }^{6}$ but their metabolic fate has remained unknown. The only reported case of detoxification of amides refers to the capsaicin, but rather than hydrolysis, the glycosylation of the phenolic moiety was observed in three Helicoverpa species. ${ }^{32}$

The identity of the carboxylic acids produced by the hydrolysis of the amides 1-7 were further confirmed by hydrolysis of the crude extracts that yielded the corresponding carboxylic acids. In general, amides are very<smiles>COc1cc(/C=C/C(=O)N2CCC=CC2=O)cc(OC)c1OC</smiles><smiles>COc1cc(CCC(=O)N2CCC=CC2=O)cc(OC)c1OC</smiles><smiles>CC(C)CNC(=O)/C=C/C=C/c1ccc2c(c1)OCO2</smiles><smiles>CC(C)CNC(=O)/C=C/CCc1ccc2c(c1)OCO2</smiles><smiles>O=C(/C=C/CCc1ccc2c(c1)OCO2)N1CCCC1</smiles><smiles>O=C(/C=C/C=C/c1ccc2c(c1)OCO2)N1CCCCC1</smiles><smiles>O=C(/C=C/CCc1ccc2c(c1)OCO2)N1CCCCC1</smiles>

Figure 1. Chemical structures of the amides from leaves of P. tuberculatum. 

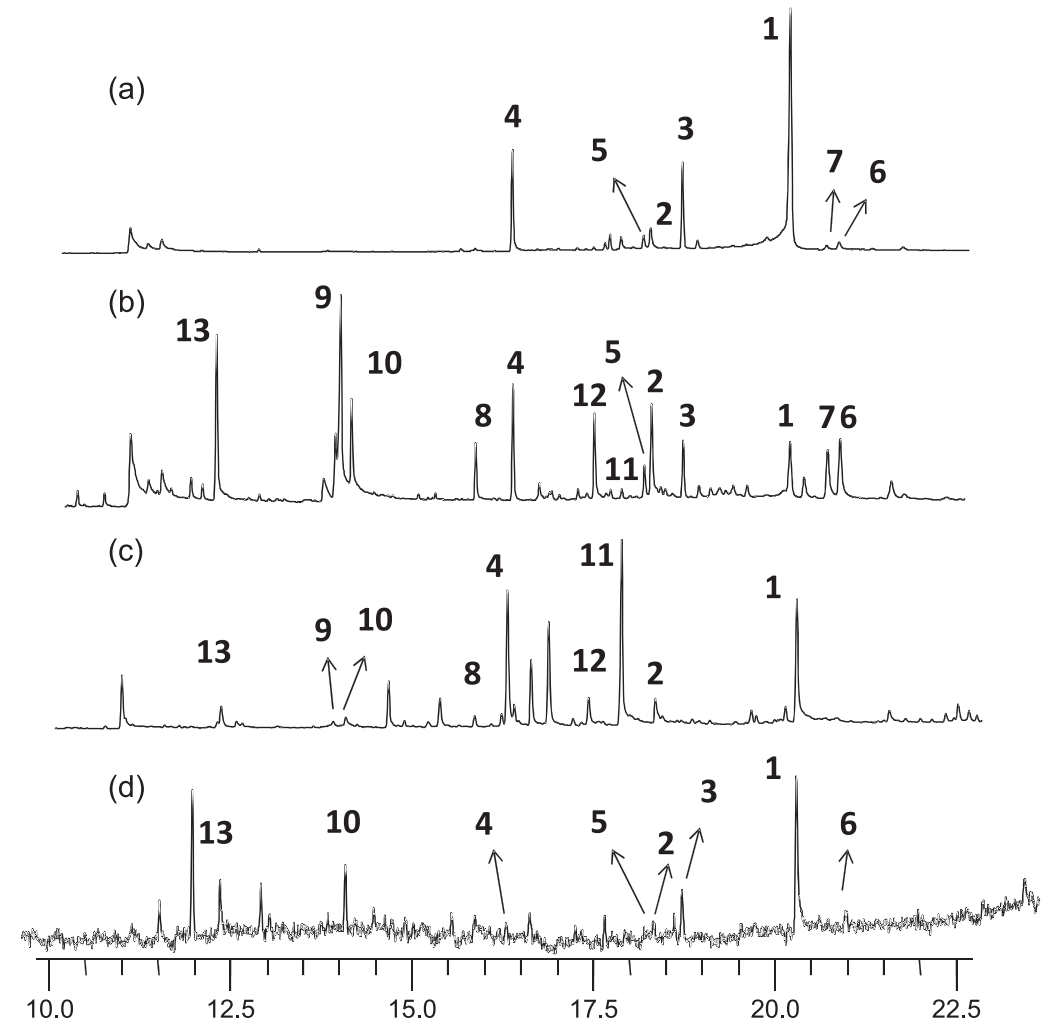

Figure 2. Chromatographic profile (GC-MS) of the extracts of the leaves of P. tuberculatum (a); fecal extracts of $H$. hectorides (b) and $N$. bipes (c) and leaves extracts from $P$. tuberculatum after saponification with $\mathrm{KOH}(\mathrm{d})$.<smiles>COc1cc(/C=C/C(=O)N2CCC=CC2=O)cc(OC)c1OC</smiles><smiles>COc1cc(CCC(=O)N2CCC=CC2=O)cc(OC)c1OC</smiles><smiles>COc1cc(/C=C/C(=O)O)cc(OC)c1OC</smiles>

\section{H. hectorides}

N. bipes<smiles>COc1cc(C(=O)O)cc(OC)c1OC</smiles><smiles>CC(C)CNC(=O)/C=C/C=C/c1ccc2c(c1)OCO2</smiles><smiles>O=C(/C=C/CCc1ccc2c(c1)OCO2)N1CCCC1</smiles><smiles>O=C(/C=C/CCc1ccc2c(c1)OCO2)N1CCCCC1</smiles><smiles>CC(C)CNC(=O)/C=C/CCc1ccc2c(c1)OCO2</smiles><smiles>O=C(/C=C/C=C/c1ccc2c(c1)OCO2)N1CCCCC1</smiles>

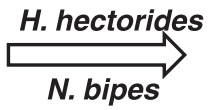<smiles>O=C(O)/C=C/C=C/c1ccc2c(c1)OCO2</smiles>

11<smiles>O=C(O)/C=C/CCc1ccc2c(c1)OCO2</smiles><smiles>O=C(O)c1ccc2c(c1)OCO2</smiles>

Figure 3. Hydrolysis of amides from $P$. tuberculatum after digestion by $N$. bipes and $H$. hectorides. 
stable to hydrolysis under physiological conditions due to the resonance stabilization. ${ }^{33-35}$ Thus, their hydrolysis in the insect's gut should be a highly specialized mechanism to circumvent insecticidal or repellent properties. In this case, the detoxification of amides was observed only for $H$. hectorides and $N$. bipes, while the three generalist Orthoptera species were not even able to consume the leaves. The weevil $N$. bipes, a beetle with polyphagous diet, is considered a pest in Southern Brazil, where it damages crops of flax, soybeans, corn and citrus fruits as well as forage grasses. ${ }^{36}$ The adult insect feeds on leaves but the larvae with below-ground habits feeding on roots of several host plants impose difficulties in controlling populations of Naupactus species. The Lepidoptera $H$. hectorides is formerly considered to be specific to Rutaceae ${ }^{34}$ but more recently, it has frequently been observed damaging leaves of several Piper species. ${ }^{23,37}$ The damaging of Piper leaves by generalist insects such as grasshoppers has also been observed under field conditions. The chemical composition in frass of grasshoppers as compared with consumed leaves has been investigated in few cases. The feces of $C$. speciosa fed on leaves of Solanum paniculatum or Mangifera indica had several elicited volatile compounds by herbivory as compared to the normal leaves. ${ }^{21}$ The migratory grasshopper Melanoplus sanguinipes was capable of biotransforming acetylchromenes by ketone reduction and hydroxylation of methyl group when applied topically. ${ }^{38}$

In our study, the biotransformation of amides from leaves of $P$. tuberculatum during the digestion by insects could be associated not only to the digestive enzymes of the insect gut, but also to the action of plant enzymes released during insects chewing. Besides, some of the compounds detected in the frass such as the free carboxylic acids could be released from cell walls of the leaves by hydrolysis and not necessarily from hydrolysis of amides.

\section{Conclusions}

The metabolic profile of frass samples from insects feeding on $P$. tuberculatum leaves suggests that all seven amides (1-7) are hydrolyzed by the weevil N. bipes and by the caterpillar of $H$. hectorides. However, the amides were deterrent to generalist herbivores such as the grasshoppers (adults and nymphs) of C. speciosa, E. trilineata and T. collaris, which were apparently not able to cope with the antifeedant properties of amides. The grasshoppers $X$. discoideus is an intermediate case in which it still can feed on P. tuberculatum leaves but is not capable to carry out hydrolysis of the amides.

\section{Supplementary Information}

Supplementary information (NMR, GC-MS) are available free of charge at http://jbcs.sbq.org.br as PDF file.

\section{Acknowledgments}

This work was funded by grants from FACEPE, FAPESP (2009/51850-9 and 2014/50316-7) and CNPq. MJK is grateful to CNPq for a research fellowship. MW thanks FACEPE for providing a scholarship.

\section{References}

1. Hwang, K. S.; Kim, Y. K.; Park, K. W.; Kim, Y. T.; Pest Manage. Sci. 2017, 73, 1564.

2. Miranda, J. E.; Navickiene, H. M. D.; Nogueira-Couto, R. H.; de Bortoli, S. A.; Kato, M. J.; Bolzani, V. S.; Furlan, M.; Apidologie 2003, 34, 409.

3. Navickiene, H. M. D.; Miranda, J. E.; Bortoli, S. A.; Kato, M. J.; Bolzani, V. S.; Furlan, M.; Pest Manage. Sci. 2007, 3, 399.

4. Park, I. K.; Lee, S. G.; Shin, S. C.; Park, J. D.; Ahn, J. Y.; J. Agric. Food Chem. 2002, 50, 1866.

5. Parmar, V. S.; Jain, S. C.; Bisht, K. S.; Jain, R.; Taneja, P.; Jha, A.; Tyagi, O. D.; Prasad, A. K.; Wengel, J.; Olsen, C. E.; Boll, P. M.; Phytochemistry 1997, 47, 597.

6. Scott, I. M.; Jensen, H. R.; Philogène, B. J. R.; Arnason, J. T.; Phytochem. Rev. 2008, 7, 65.

7. Scott, W. P.; McKibben, G. H.; J. Econ. Entomol. 1978, 71, 343.

8. Siddiqui, S. B.; Gulzar, T.; Begum, S.; Rasheed, M.; Saftar, F. A.; Afshan, F.; Helv. Chim. Acta 2003, 86, 2760.

9. Yang, Y. C.; Lee, S. G.; Lee, H. K.; Kim, M. K.; Lee, S. H.; Lee, H. S.; J. Agric. Food Chem. 2002, 50, 3765.

10. Siddiqui, B. S.; Gulzar, T.; Mahmood, A.; Begum, S.; Khan, B.; Afshan, F.; Chem. Pharm. Bull. 2004, 52, 1349.

11. Paula, V. F.; Barbosa, L. C. D.; Demuner, A. J.; Piló-Veloso, D.; Picanço, M. C.; Pest Manage. Sci. 2000, 56, 168.

12. Bernard, C. B.; Krishnamurty, H. G.; Chauret, D.; Durst, T.; Philogène, B. J. R.; Sánchez-Vindas, P.; Hasbun, C.; Poveda, L.; Román, L. S.; Arnason, J. T.; J. Chem. Ecol. 1995, 21, 801.

13. Miyakado, M.; Nakayama, I.; Yoshioka, H.; Nakatani, N.; Agric. Biol. Chem. 1979, 43, 1609.

14. Dyer, L. A.; Dodson, C. D.; Beihoffer, J.; Letourneau, D. K.; J. Chem. Ecol. 2001, 27, 581 .

15. Dyer, L. A.; Dodson, C. D.; Stireman, J. O.; Tobler, M. A.; Smilanich, A. M.; Fincher, R. M.; Letourneau, D. K.; J. Chem. Ecol. 2003, 29, 2499.

16. Aguiar, A. R.; Alvarenga, E. S.; Silva, E. M. P.; Farias, E. S.; Picanço, M. C.; Pest Manage. Sci. 2019, 75, 1689. 
17. Kaushik, P.; Sarkar, D. J.; Chander, S.; Rana, V. S.; Shakil, N. A.; J. Environ. Sci. Health, Part B 2019, 54, 489.

18. Tsikolia, M.; Bernier, U. R.; Agramonte, N. M.; Estep, A. S.; Becnel, J. J.; Tabanca, N.; Linthicum, K. J.; Gross, A. D.; Guerin, P. M.; Kröber, T.; Bloomquist, J. R.; Pestic. Biochem. Physiol. 2018, 151, 40.

19. Ramos, C. S.; Kato, M. J.; J. Braz. Chem. Soc. 2009, $20,560$.

20. Ramos, C. S.; Kato, M. J.; Chemoecology 2013, 23, 143.

21. Ramos, C. S.; Ramos, N. S. M.; Silva, R. R.; Câmara, C. A. G.; Almeida, A. V.; J. Insect Physiol. 2012, 58, 1663.

22. Ramos, C. S.; Souza, L. J.; Kato, M. J.; Batista, R.; Chemoecology 2012, 22, 39.

23. Ramos, C. S.; Vanin, S. A.; Kato, M. J.; Phytochemistry 2008, 69, 2157.

24. Ramos, C. S.; Vanin, S. A.; Kato, M. J.; Chemoecology 2009, $19,73$.

25. Navickiene, H. M. D.; Alécio, A. C.; Kato, M. J.; Bolzani, V. S.; Young, M. C. M.; Cavalheiro, A. J.; Furlan, M.; Phytochemistry 2000, 55, 621 .

26. Silva, R. V.; Navickiene, H. M. D.; Kato, M. J.; Bolzani, V. S.; Méda, C. I.; Young, M. C. M.; Furlan, M.; Phytochemistry 2002, $59,521$.

27. Choochana, P.; Moungjaroen, J.; Jongkon, N.; Gritsanapan, W.; Tangyuenyongwatana, P.; Pharm. Biol. 2015, 53, 477.

28. Martins, R. C. C.; Lago, J. H. G.; Albuquerque, S.; Kato, M. J.; Phytochemistry 2003, 64, 667.
29. Gonzalez-Laredo, R. F.; Karchesy, J. J.; Planta Med. 1996, 62, 582.

30. Mishra, S.; Narain, U.; Mishra, R.; Misra, K.; Bioorg. Med. Chem. 2005, 13, 1477.

31. Araújo-Junior, J. X.; Barreiro, E. J.; Parente, J. P.; Fraga, C. A. M.; Synth. Commun. 1999, 29, 263.

32. Ahn, S. J.; Badenes-Pérez, F. R.; Heckel, D. G.; J. Insect Physiol. 2011, 57, 1212.

33. Glüsenkamp, K. H.; Mengede, C.; Drosdziok, W.; Jähde, E.; Rajewsky, M. F.; Bioorg. Med. Chem. Lett. 1998, 8, 285.

34. Lopez, X.; Mujika, J. I.; Blackburn, G. M.; Karplus, M.; J. Phys. Chem. A 2003, 107, 2304.

35. Yan, Y. M.; Atsumi, M.; Yuan, D. Q.; Fujita, K.; Tetrahedron Lett. 2000, 41, 1825.

36. Lanteri, A. A.; Guedes, J. C.; Parra, J. R. P.; Neotrop. Entomol. 2002, 31, 561.

37. Vanin, S. A.; Ramos, C. S.; Guimarães, E. F.; Kato, M. J.; Rev. Bras. Entomol. 2008, 52, 72.

38. Isman, M. B.; Proksch, P.; Witte, L.; Arch. Insect Biochem. Physiol. 1987, 6, 109.

Published online: October 7, 2019 